\title{
Effect of reef framework and bottom sediment on nutrient enrichment in a coral reef of the Gulf of Aqaba, Red Sea
}

\author{
Mohammed Rasheed ${ }^{1,2, *}$, Mohammad I. Badran $^{2}{ }^{,}$Claudio Richter $^{3}$, Markus Huettel ${ }^{1}$ \\ ${ }^{1}$ Max Planck Institute for Marine Microbiology, Celsiusstraße, 28359 Bremen, Germany \\ ${ }^{2}$ Marine Science Station, University of Jordan and Yarmouk University, Aqaba, Jordan \\ ${ }^{3}$ Centre for Tropical Marine Ecology ZMT, Fahrenheitstraße 6, 28359 Bremen, Germany
}

\begin{abstract}
Inorganic nutrients and chlorophyll a concentrations were measured bi-weekly in a transect across a coral reef in the Gulf of Aqaba over a period of $1 \mathrm{yr}$. The nutrient and chlorophyll concentrations were compared to those in adjacent offshore waters (400 m depth). In reef and offshore waters, nutrient (ammonium, nitrite, nitrate, phosphate and silicate) and chlorophyll a data showed seasonal changes, with high concentrations in winter and low concentrations in summer. However, throughout the summer, nutrient concentrations in the coral reef waters significantly exceeded those in the offshore waters, while this difference was less pronounced in winter. This difference was caused by nutrient release from regenerative spaces in the reef framework and coral sand. In the reef framework water (i.e. cavity water), nutrient concentrations were 1.2- to 2.3-fold higher than those in the surrounding waters, corresponding to fluxes of $14.5 \mathrm{mmol} \mathrm{m}^{-2} \mathrm{~d}^{-1}$ for ammonium, $7.7 \mathrm{mmol} \mathrm{m}^{-2} \mathrm{~d}^{-1}$ for nitrate, $0.9 \mathrm{mmol} \mathrm{m}^{-2} \mathrm{~d}^{-1}$ for nitrite, and $1.3 \mathrm{mmol} \mathrm{m}^{-2} \mathrm{~d}^{-1}$ for phosphate. In the less permeable reef sediments, nutrient concentrations exceeded those of the free-stream waters by factors of 15 to 80 . Here, the calculated diffusive fluxes were $0.06 \mathrm{mmol} \mathrm{m}^{-2} \mathrm{~d}^{-1}$ for ammonium, $0.03 \mathrm{mmol} \mathrm{m} \mathrm{m}^{-2} \mathrm{~d}^{-1}$ for nitrate, $0.01 \mathrm{mmol} \mathrm{m}^{-2} \mathrm{~d}^{-1}$ for nitrite, $0.01 \mathrm{mmol} \mathrm{m}^{-2} \mathrm{~d}^{-1}$ for phosphate, and $0.07 \mathrm{mmol} \mathrm{m}^{-2} \mathrm{~d}^{-1}$ for silicate. Our results highlight the importance of the reef framework and coral sand for the trapping and mineralization of particulate organic matter and the regeneration of nutrients in oligotrophic coral reef waters.
\end{abstract}

KEY WORDS: Nutrients $\cdot$ Coral reef $\cdot$ Seasonality $\cdot$ Porewater $\cdot$ Reef framework $\cdot$ Coral sand

\section{INTRODUCTION}

Although most coral reefs grow in oligotrophic waters (Furnas 1992), they belong to the most productive coastal marine ecosystems (Sorokin 1993). The exchange of substances between reef, open water, land and atmosphere is small relative to their concentrations and turnover within the coral reefs. The high biomass and productivity of coral reefs is explained by the tight internal recycling of matter (Wiebe et al. 1975, Andrews \& Müller 1983, Risk \& Müller 1983). Gross

*E-mail: my_rasheed@yahoo.com primary production in coral reef waters has been shown to be 1 to 2 orders of magnitude higher than in the surrounding oligotrophic water (d'Elia \& Wiebe 1990, Adey 1998). Reef-related physical and biological processes mediate intensive exchange of dissolved and particulate matter between the coral reef and the water in the reef environment. Coral sands and reef framework may play important roles in this exchange process.

In most reef ecosystems, corals occupy roughly half the surface area, and sands cover the other half. Due to the porous structure of the coral sand, its permeability is relatively high and the porosity of the reef sediment can reach $50 \%$. Pore water analyses in these cal- 
careous sediments revealed elevated nutrient concentrations relative to the overlying bottom water (Holm 1978, Smith et al. 1981, Arenas \& de la Lanza 1983, Entsch et al. 1983, Nixon \& Pilson 1983, Williams 1984, Williams et al. 1985, Furnas et al. 1993, Szmant \& Forrester 1996).

Beneath the living surface of the coral reefs, coral skeletal remains and other calcareous biogenic materials form a highly permeable framework, where the volume of coral reef cavities may reach up to half the bulk volume (Ginsburg 1983). These framework cavities are inhabited by a wide variety of organisms (Kobluk \& van Soest 1989). Organic matter trapped within the framework or imported by the reef fauna is consumed by the organisms that colonize the cavities and that return ammonia and phosphate to the framework water (Ferrer \& Szmant 1988). Nutrient concentrations in reef cavities, therefore, exceed those of waters surrounding the reef (Risk \& Müller 1983, Ayukai 1993, Richter et al. 2001).

Because of their large specific surface areas, coral sands and reef framework may have an important biocatalytic function and may act as nutrient buffers in reef ecosystems exposed to seasonal nutrient changes. Seasonal variability of the nutrient supply in coral reef environments has received little attention due to the perception that seasonal fluctuations are less pronounced in tropical climates. Nonetheless, high- latitude reefs, such as those of the Gulf of Aqaba, undergo strong seasonal variations in primary productivity (Kinsey 1977) that are unexpected on the basis of temperature and light fluctuations alone.

Our understanding of the relationship between reef productivity and nutrient availability is limited, despite the importance of nutrients for the growth and health of corals (Ward 1990, Torrance 1991, Hallock et al. 1993, Atkinson et al. 1995). In this study, we investigated the seasonal changes of chlorophyll $a$ and nutrients in the water column and in a fringing reef ecosystem of the Gulf of Aqaba, and we measured coral framework and sediment pore-water nutrient concentrations in order to assess the importance of framework and sediment in the nutrient balance of the coral reef.

\section{MATERIALS AND METHODS}

The study was conducted in a well-developed coral reef located in the northern Gulf of Aqaba in a marine reserve close to the Marine Science Station in Aqaba. Water samples were collected concurrently from the reef site and an offshore site $3 \mathrm{~km}$ from the Marine Science Station (Fig. 1A). Along the reef transect, surface and bottom water (ca. $50 \mathrm{~cm}$ above the sediment) were sampled biweekly at stations 5, 10, 20, and $30 \mathrm{~m}$ from the bottom (Fig. 1B). At the stations at 20 and $30 \mathrm{~m}$ water depth, additional samples were taken at $10 \mathrm{~m}$ depth intervals. The offshore reference station was sampled at water depths of 0.5 and $25 \mathrm{~m}$. The bottom-water samples were collected by divers, while all other samples were collected with Niskin bottles. All samples were kept on ice until analysis. In the laboratory, 11 of each sample was filtered through a pre-rinsed $0.45 \mu \mathrm{m}$ cellulose-membrane filter and analyzed for ammonium, nitrite, nitrate, phosphate and silicate concentrations according to Strickland \& Parsons (1972). The material on the membrane filter was used for the determination of chlorophyll a based on the method published by Arar \& Collins (1992), using a Turner Designs, TD-700 fluorometer.

In June and December 1998, water samples from coral reef cavities and free-flowing reef waters were simultaneously taken at hourly intervals over a period of $24 \mathrm{~h}$ (Fig. 1B). Water was collected using a multichannel peristaltic pump mounted on a boat, using 
Table 1. Annual average (SD) nutrient $(\mu \mathrm{M})$ and chlorophyll a $\left(\mu \mathrm{g} \mathrm{l^{-1 }}\right)$ concentrations in offshore and coral reef waters during summer $(n=70)$ and winter $(\mathrm{n}=28)$

\begin{tabular}{|lcccc|}
\hline \multirow{2}{*}{ Variable } & \multicolumn{2}{c}{ Reef water } & \multicolumn{2}{c|}{ Offshore water } \\
& Summer & Winter & Summer & Winter \\
\hline Inorganic nitrogen & $0.35(0.09)$ & $0.65(0.08)$ & $0.13(0.03)$ & $0.58(0.05)$ \\
Phosphate & $0.06(0.01)$ & $0.09(0.01)$ & $0.02(0.01)$ & $0.07(0.01)$ \\
Silicate & $1.05(0.14)$ & $1.78(0.10)$ & $0.70(0.01)$ & $1.43(0.03)$ \\
Chlorophyll a & $0.19(0.02)$ & $0.23(0.03)$ & $0.14(0.02)$ & $0.23(0.02)$ \\
& & & & \\
\hline
\end{tabular}

where $F$ is the flux $\left(\mathrm{mmol} \mathrm{m} \mathrm{m}^{-2} \mathrm{~d}^{-1}\right)$, ø is sediment porosity, $D$ is the coefficient of diffusion $\left(\mathrm{m}^{2} \mathrm{~d}^{-1}\right)$, and $\mathrm{d} C / \mathrm{d} z$ is the concentration gradient at the sedimentwater interface $\left(\mathrm{mmol} \mathrm{m}^{-4}\right)$. Diffusion coefficients for ammonium, nitrate, nitrite and phosphate were taken from Li \& Gregory (1974) for a water temperature of $25^{\circ} \mathrm{C}$ and corrected for a tortuosity using a porosity of 0.47 and the tortuosity-porosity relationship reported by Beekman (1990). The

$10 \mathrm{~m}$ long, $5 \mathrm{~mm}$ diameter silicone tubing inserted into 8 randomly selected cavities within a $4 \mathrm{~m}$ diameter coral pinnacle located at a depth of 3 to $6 \mathrm{~m}$. Tubes were fixed axially into $\sim 6 \mathrm{~cm}$ wide, $\sim 30 \mathrm{~cm}$ deep cavities using elastic plastic rods. Tubes were inserted two-thirds of the way into the cavities, i.e. at $\sim 20 \mathrm{~cm}$ distance from the entrance. Free-flowing water was collected with 2 tubes fixed on moorings $3 \mathrm{~m}$ upstream from the pinnacle; $100 \mathrm{ml}$ samples were drawn at $50 \mathrm{ml}$ $\min ^{-1}$ and taken to the laboratory for subsequent analysis of nutrients. Between samplings, the flow was reversed, using double-distilled water at rates of $2 \mathrm{ml}$ $\min ^{-1}$ to avoid fouling of the tubing. With an average volume of the sampled cavities of $\sim 31$ and a water residence time of less than $5 \mathrm{~min}$, we found no dilution effect of the freshwater on salinity in the cavities. Nutrient fluxes between coral reef cavities and free-flowing waters were calculated according to the formula

$$
F=\Delta N \times V_{\mathrm{c}} / T
$$

where $\Delta N$ is the concentration difference between the cavity and free-flowing reference $\left(\mathrm{mmol} \mathrm{m}^{-3}\right), V_{\mathrm{c}}$ is the volume of cavities per unit area of reef $\left(\mathrm{m}^{3} \mathrm{~m}^{-2}\right)$, and $T$ is the residence time of water in the cavities. For the upper $0.2 \mathrm{~m}$ of framework investigated, $V_{\mathrm{c}}$ was $0.07 \mathrm{~m}$ (Richter et al. 2001). A conservative estimate for $T$ is 300 s (Richter \& Wunsch 1999).

From June 1999 until March 2000, interstitial water of the coral reef sediments were sampled at a $5 \mathrm{~m}$-deep reef site (Fig. 1B) using a method similar to that described by Hesselein (1976). The sediments in this site consist mainly of carbonate sands, with a medium grain size of $500 \mu \mathrm{m}$, an average porosity of $47 \%$, a permeabilty of $143 \times 10^{-12} \mathrm{~m}^{2}$, an organic content of $0.5 \%$, and a calcium carbonate content of $80 \% ; 50 \mathrm{ml}$ of the filtered pore water was diluted to $250 \mathrm{ml}$ with distilled deionized water for nutrient analyses. The pore-water nutrient concentrations were compared to those of the bottom water overlying the sediment. Minimum fluxes of $\mathrm{NH}_{4}{ }^{+}, \mathrm{NO}_{2}{ }^{-}$, $\mathrm{NO}_{3}{ }^{-}, \mathrm{PO}_{4}{ }^{-3}$ and $\mathrm{Si}(\mathrm{OH})_{4}$ from the sediment were calculated according to Fick's first law of diffusion:

$$
F=\varnothing \times D \times \mathrm{d} C / \mathrm{d} z
$$

value for silicate was taken from Lerman (1979) and Callender \& Hammond (1982) and corrected for tortuosity. The calculated diffusion coefficients were 8.85 , $6.66,6.70,2.97$ and $5.89 \times 10^{-5} \mathrm{~m}^{-2} \mathrm{~d}^{-1}$ for ammonium, nitrate, nitrite, phosphate and silicate respectively.

To assess whether nutrients were significantly different in coral reef waters from those in the offshore waters, ANOVA (5\% significance level) was performed based on a calculation of the differences in the average of concentrations between coral reef waters and offshore waters in summer and winter.

\section{RESULTS}

In order to compare nutrient concentrations of reef and offshore waters, surface and $25 \mathrm{~m}$ samples of the offshore waters were averaged and plotted with the average of the coral reef waters from various depths against time (Fig. 2). Nutrient and chlorophyll a concentrations in reef and offshore waters showed seasonal changes, with high concentrations in winter and low concentrations in summer. The concentrations began to increase in October. Nutrient and chlorophyll a concentrations in the reef waters exceeded those in the offshore waters (Fig. 2, Table 1), particularly in summer, when inorganic nitrogen and phosphate concentrations exceeded offshore values by up to 3 times. The pattern was less consistent during win-

Table 2. Mean differences in nutrient $(\mu \mathrm{M})$ and chlorophyll a $\left(\mu \mathrm{g} \mathrm{l}^{-1}\right.$ ) concentrations between reef and offshore waters in summer and winter. $\mathrm{p}$-values were obtained from ANOVA at significance level of $5 \%$. ${ }^{*}$ Significant difference

\begin{tabular}{|lrrrr|}
\hline Variable & \multicolumn{2}{c}{$\begin{array}{c}\text { Summer } \\
\text { Mean } \\
\text { difference }\end{array}$} & \multicolumn{3}{c|}{$\begin{array}{c}\text { Winter } \\
\text { Mean } \\
\text { difference }\end{array}$} \\
\hline Inorganic nitrogen & 0.22 & $<0.0001^{*}$ & 0.07 & 0.4761 \\
Phosphate & 0.04 & $<0.0001^{*}$ & 0.02 & $0.0057^{*}$ \\
Silicate & 0.35 & $0.0015^{*}$ & 0.35 & $0.0178^{*}$ \\
Chlorophyll a & 0.05 & $0.0316^{*}$ & 0.00 & 0.7394 \\
\hline
\end{tabular}


ter, when gradient reversals occurred, both for inorganic nitrogen (e.g. nitrate, February through April: Fig. 2) and chlorophyll a (January through March: Fig. 2). As a result, moderate cross-shore differences were found only for phosphate and silicate in winter, as
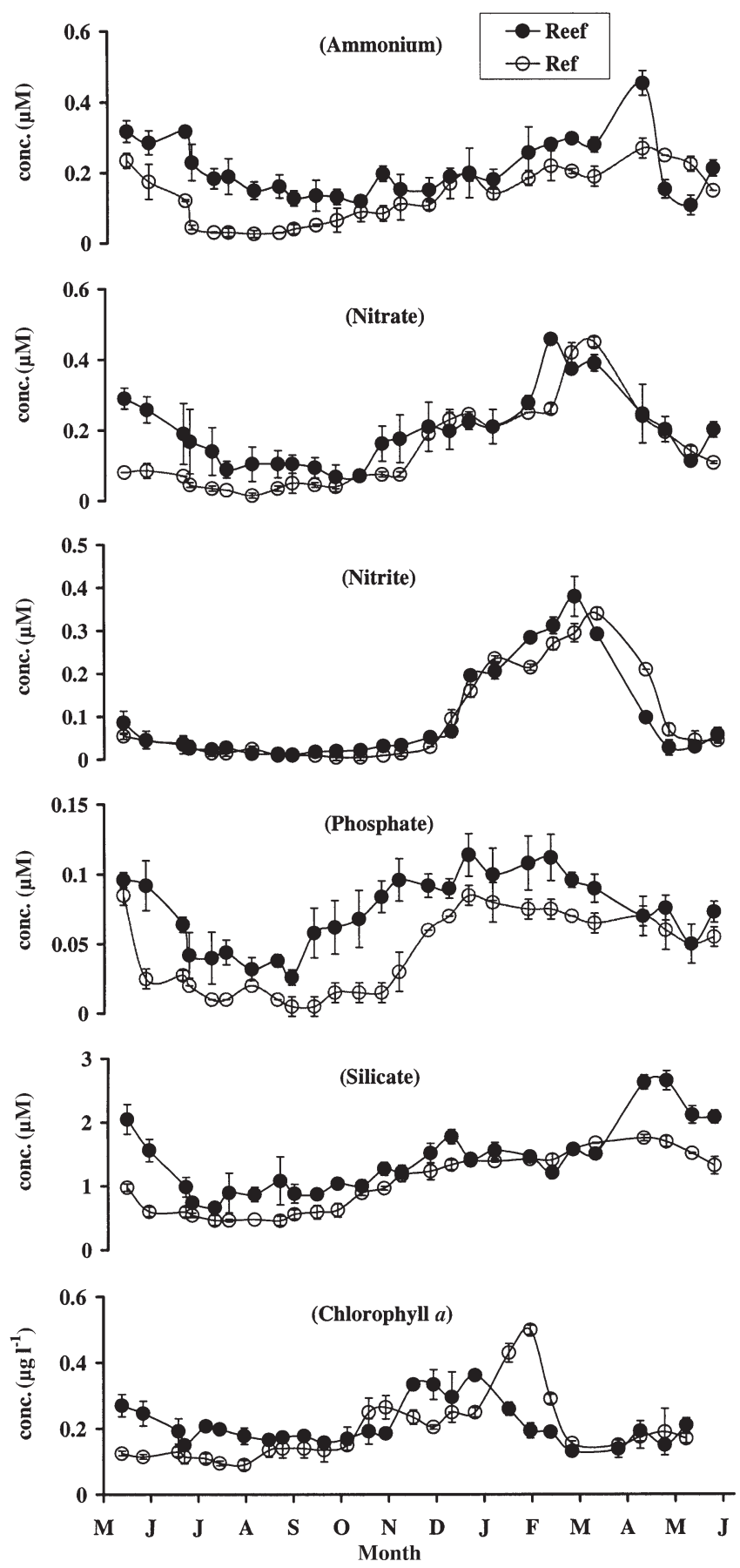

Fig. 2. Nutrient and chlorophyll a concentrations in coral reef (Reef) and offshore reference (Ref) waters during the period May 1997 to May 1998
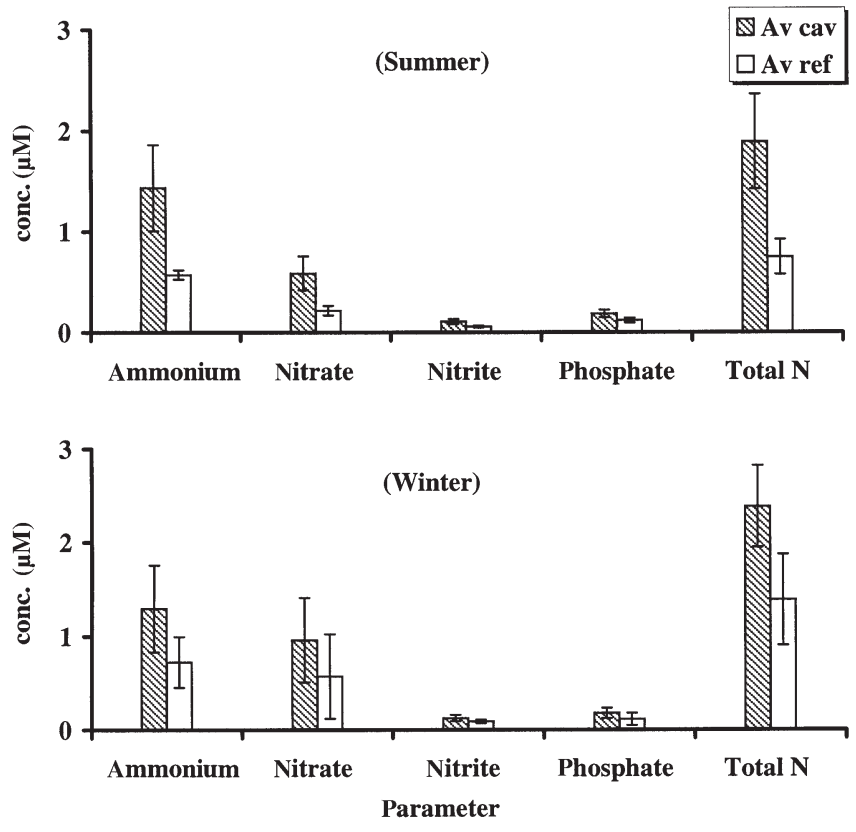

Fig. 3. Average nutrient concentrations in the framework of the coral reef (Av cav) and surrounding waters (Av ref)

opposed to strong and highly significant differences for all parameters in summer (Table 2).

Within the reef framework, nutrient concentrations were higher than in the freestream waters (Fig. 3) in approximately $90 \%$ of the cases. Much higher nutrient concentrations were found in sediment pore waters compared to concentrations in the water above the sediment (factors of 21 to 80 in summer and 15 to 74 in winter: Fig. 4).

\section{DISCUSSION}

This study shows, for the first time, clear seasonal changes in nutrient and chlorophyll $a$ in reef and offshore waters, as well as differences in these parameters between the two. Enhancement of nutrient concentrations in reef water was found particularly during summer. Higher nutrient concentrations were found in the sediment pore water and in the reef framework than in the surrounding water. This steep concentration gradient would result in fluxes of these nutrients to the surrounding water.

\section{Seasonal pattern of nutrients in coral reef waters}

According to Furnas et al. (1990), Hatcher \& Hatcher (1981), and Ayukai (1993), it is difficult to detect seasonal variations in reef-water nutrient concentrations 
by sampling at 1 mo or longer intervals because of the strong short-term variations in the reef waters. Our results demonstrate temporal and spatial changes in the nutrient concentrations in the coastal environment of the northern Gulf of Aqaba, whereas no significant difference in current speed and direction between summer and winter were found (M. Rasheed et al. unpubl. data). We have shown that the coral reef ecosystem in the Gulf of Aqaba is subjected to seasonal changes, with elevated concentrations of all measured nutrients in fall and winter. The main 2 reasons which could cause these seasonal changes are (1) deep-water column-mixing during winter increasing the nutrient concentrations in the coastal waters and boosting phytoplankton growth (Venrick et al. 1973, Souvermezoglou et al. 1989, Lindell \& Post 1995), and (2) watercolumn stratification and increased light intensities during summer, which result in a depletion of the inorganic nutrients by enhanced primary production (Olson 1981, Souvermezoglou et al. 1989).

\section{Comparison between nutrient and chlorophyll a values in reef and offshore waters}

In our study we found spatial differences in nutrient concentrations between reef water and offshore water adjacent to the reef. During the summer months, when the offshore water was nutrient-depleted, concentrations of nutrients and chlorophyll $a$ in the reef water were higher than in the offshore water. During winter, strong vertical mixing reduced the differences in nutrient and chlorophyll a concentrations between reef and offshore waters. Vertical mixing moved deep water, rich in nutrients, up into the water column (Venrick et al. 1973, Klinker et al. 1978, Levanon-Spanier et al. 1979, Olson 1981, Al-Najjar 2000), while horizontal mixing caused nutrient equilibration between reef and offshore waters. Nitrogen enrichment of coral reef waters has been reported by several authors (Meyer \& Shultz 1985, Blanchot et al. 1989, Tribble et al. 1990, Bell 1991), and the reef in the Gulf of Aqaba showed similar trends (Badran \& Foster 1998). Enhanced primary productivity during winter months in the Gulf of Aqaba was recorded by Levanon-Spanier et al. (1979).

\section{Possible reasons for higher nutrient concentrations in reef waters}

Increased nutrient concentrations in reef waters can originate from anthropogenic sources such as nutrientrich groundwater input (d'Elia et al. 1981, Lewis 1985), sewage discharge (Johannes 1975) and terrestrial runoff (Marsh 1977). However, these sources are negligi- ble in our study area because the reef is an environmentally protected zone and there is no groundwater input (no salinity change was recorded in the study area) and very little rainfall throughout the year. The higher silicate concentrations could be attributable partly to an influx of atmospheric silicate-rich desert dust (Alfuqaha unpubl. data). We suggest that the higher nutrient concentrations in the reef are caused by the efficient trapping and decomposition of suspended particles by the reef framework, coral sands and reef biota, as well as nitrogen fixation by organisms living in the reef environment.

\section{Framework}

Our study has shown that the concentrations of nutrients in the framework water were higher than those in the free-flowing water (Fig. 3), which would cause nutrient fluxes from the framework to the surrounding water. The average fluxes in summer and winter from the framework reached approximately $14.5 \mathrm{mmol}$
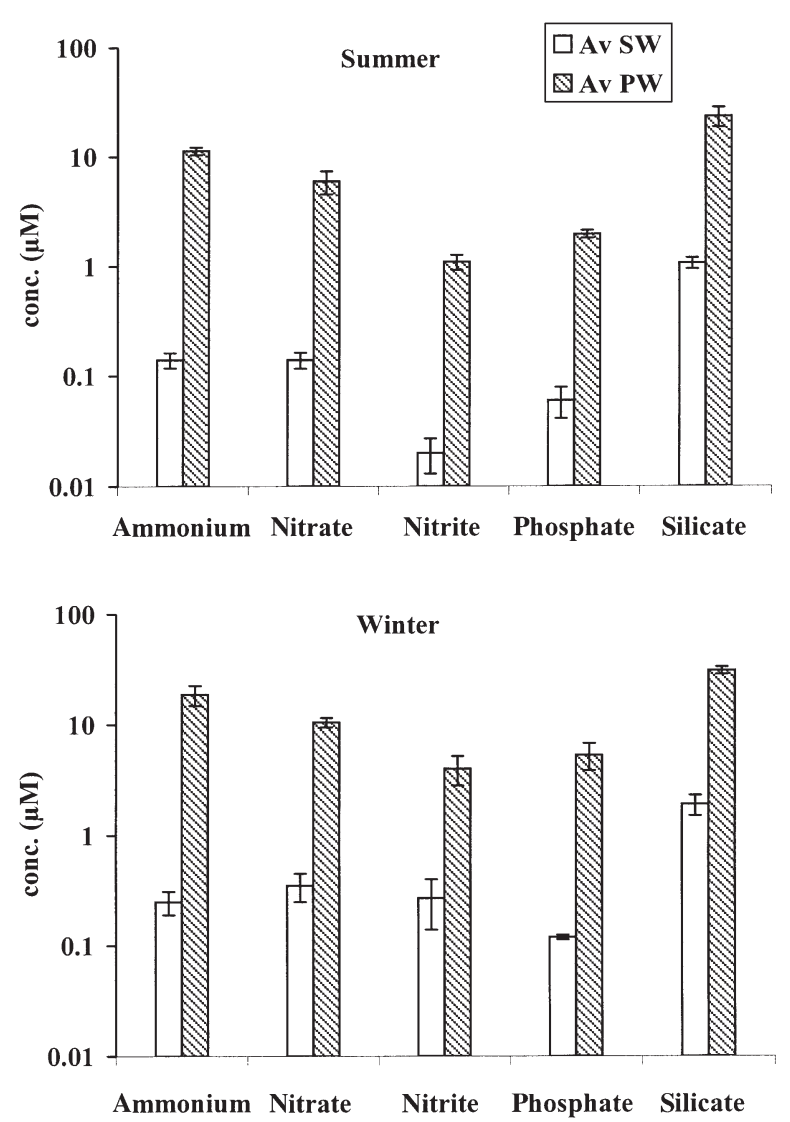

Fig. 4. Average nutrient concentrations during summer and winter (June 1999 to March 2000) in pore water (Av PW) and sediment water interface (Av SW) of the coral reef 


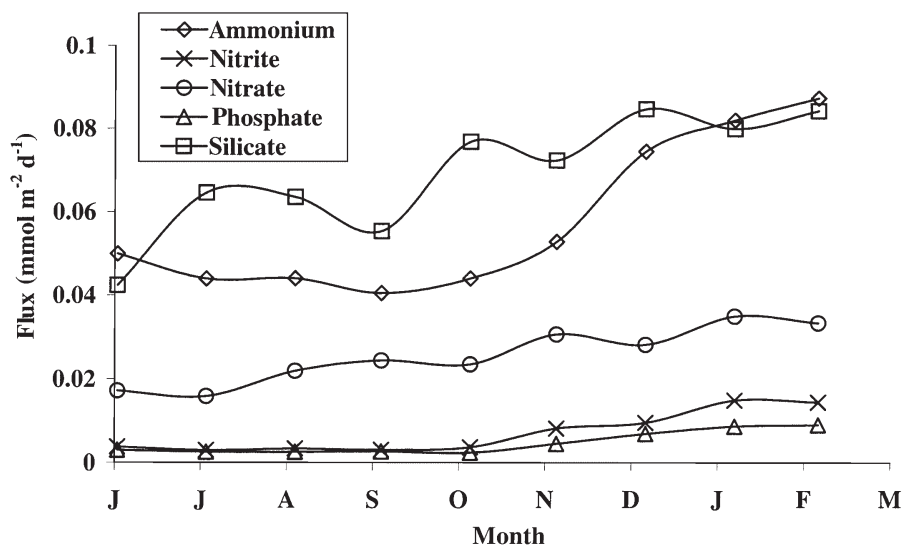

Fig. 5. Calculated nutrient fluxes from the sediment to the water column during the period June 1999 to March 2000

$\mathrm{m}^{-2} \mathrm{~d}^{-1}$ for ammonium, $7.7 \mathrm{mmol} \mathrm{m}{ }^{-2} \mathrm{~d}^{-1}$ for nitrate, $0.9 \mathrm{mmol} \mathrm{m}^{-2} \mathrm{~d}^{-1}$ for nitrite, and $1.3 \mathrm{mmol} \mathrm{m}^{-2} \mathrm{~d}^{-1}$ for phosphate. These fluxes may have added more nutrients to the reef water, particularly during summer, when the concentrations were low (Fig. 2). Three mechanisms may be responsible for the higher nutrient concentrations in the framework: (1) decomposition of organic matter enclosed in the framework carbonates that had been overgrown by corals (e.g. coral tissue, boring organisms, coralline algae), (2) suspended particulate matter, including small phytoplankton and bacteria that had been efficiently trapped by the abundant suspension feeders living within the reef framework (Gast et al. 1998, Richter \& Wunsch 1999, Richter et al. 2001), and (3) remineralization of faeces from migrating invertebrates and fishes, which forage on and above the reef and use cavities as a temporary shelter (Bray et al. 1981, Meyer et al. 1983). Similar findings were reported by Ferrer \& Szmant (1988) and Tribble et al. (1988), who measured increased nutrient concentrations in the cavities of the reef of Belize Barrier Reef and Kaneohe Bay respectively, and a net flux of nutrients from the reef framework to the surrounding water. These findings indicate that the reef framework is an important site for organic matter mineralization in the reef (Andrews \& Müller 1983, Szmant-Froelich 1983, Sansone 1985, Buddemeier \& Oberdorfer 1986, Tribble et al. 1986, 1988) and suggest that the framework may act as a temporal nutrient source in the reef environment.

\section{Coral sands}

We measured increased nutrient concentrations in the pore water of the sediment relative to the overlying water during summer and winter (Fig. 4). This steep concentration gradient would result in a net flux of nutrients from the pore water to the overlying water (Fig. 5). Fluxes of ammonia, nitrite, nitrate and phosphate increased during the winter months (December to March: Fig. 5). The average fluxes over the whole year were $0.06 \mathrm{mmol} \mathrm{m}^{-2} \mathrm{~d}^{-1}$ for ammonium, $0.03 \mathrm{mmol}$

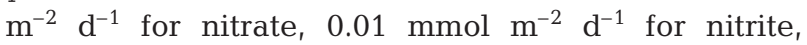
$0.01 \mathrm{mmol} \mathrm{m}^{-2} \mathrm{~d}^{-1}$ for phosphate, and $0.07 \mathrm{mmol} \mathrm{m}^{-2}$ $\mathrm{d}^{-1}$ for silicate. However, the calculated fluxes only represent the diffusive fluxes from the sediment, as the calculation we used (Fick's law of diffusion) does not include fluxes caused by bioturbation and advective pore-water exchange (Clavero et al. 2000). Laboratory core incubation resulted in silicate fluxes which exceeded the calculated silicate flux by a factor of 20 (Rasheed et al. unpubl. data), suggesting that both bioturbation and advective pore-water exchange probably added to the flux.

This indicates that the coarse-grained carbonate reef sediments may act as a biocatalytic converter, similar to the porous framework. We suggest that organic matter filtered from the water column when bottom currents interact with the permeable sediment (Huettel et al. 1996, Huettel \& Rusch 2000) is decomposed in the sedimentary microbial food chain. The products of the mineralization, the nutrients, are then released into the pore water and overlying water column. Increased nutrient concentrations in the pore water of reef sediments were also reported by Capone et al. (1992) for the Great Barrier Reef, Szmant \& Forrester (1996) for the Florida Coral Reef, and Ciceri et al. (1999) for the northern lagoon of Venice. Nutrient release from reef pore waters to the water column was reported by several authors (e.g. Fuentes \& Espino 1990, Bertuzzi et al. 1996, Charpy-Roubaud et al. 1996, Ciceri et al. 1999). The flux of ammonium in our study $\left(0.06 \mathrm{mmol} \mathrm{m}^{-2} \mathrm{~d}^{-1}\right)$ was lower than the fluxes reported by Charpy-Rouband et al. (1996) (0.16 mmol m-2 $\left.\mathrm{d}^{-1}\right)$ and Bertuzzi et al. (1996) $\left(0.3 \mathrm{mmol} \mathrm{m}^{-2} \mathrm{~d}^{-1}\right)$. However, phosphate flux in our study was higher compared to the previous 2 studies $(0.010,0.004$, and 0.001 respectively). The differences in the flux values resulted from different nutrient concentrations in the water column and in the pore water, which might be attributable to the differences in the organic matter loading and different chemical and physical properties of the study areas (Shum \& Sundby 1996, Hulthe et al. 1998). Charpy-Roubaud et al. (1996) found that aerobic bacteria that live in coral sediment could mineralize organic compounds to mineral end-products. In most tropical shallow marine environments like the Gulf of Aqaba, the highest metabolic activity is associated with the benthos (Zieman 1982, d'Elia \& Wiebe 1990). 


\section{Reef biota}

Corals, mollusks, polychaetes, echinoderms and a variety of other reef-dwelling organisms can efficiently filter and digest organic particles from water in the reef and thereby also increase the concentration of nutrients in the reef water relative to the offshore water (Hatcher \& Hatcher 1981, Andrews \& Müller 1983, Tribble et al. 1988, Larned 1999).

\section{Nitrogen fixation}

Nitrogen fixation in the different habitats within the reef has been reported in several studies (e.g. Wiebe et al. 1975, Goldner 1980, Wilkinson et al. 1984). According to Crossland \& Barnes (1976), corals themselves do not have the ability to fix nitrogen, but endolithic organisms in the coral skeleton do. Shashar et al. (1994) reported a fixation rate of 0.6 to $1.0 \mathrm{mmol} \mathrm{N}_{2} \mathrm{~m}^{-2}$ $\mathrm{d}^{-1}$ in the Gulf of Aqaba and reported that $70 \%$ of the fixation occurred in the sand-covered lagoon.

\section{CONCLUSIONS}

Our study has shown seasonal changes in the nutrient concentrations in the reef and a nutrient gradient between reef water and offshore water during summer. In winter, high nutrient concentrations in the coastal zone in the Gulf of Aqaba caused by enhanced water-column mixing remove this gradient. In summer, particle trapping and biocatalytic conversion of dissolved and particulate material in framework and reef sands increase the nutrient concentrations in the reef water relative to the offshore water. This nutrient availability during summer permits a higher primary productivity in the reef environment during this period in comparison to the offshore water, as indicated by the chlorophyll a data. We conclude that the decomposition activity and buffer capacity of the coral sands and reef framework play an important role in the support of primary productivity in the coral reef ecosystem during phases of nutrient depletion in the water column. During the fall and winter months, sands and framework accumulate nutrients (due to sorption and binding processes) and particulate organic matter. This organic matter is decomposed in the pore space of the sand and reef framework, and the resulting nutrients may be gradually released during the summer months.

Acknowledgements. This work forms part of the Red Sea Programme and has been funded by the German Federal Ministry of Education and Research (BMBF grant no. 03F0245A).
Thanks are due to the director and the staff members of the Marine Science Station for their support during this study. Thanks are also due to Khalid Al-Tarabeen for his assistance in the laboratory and to Tariq Al-Salman, Riyad Manasreh, Saber Al-Rousan, Britta Munkes, Iris Kötter and Mark Wunsch for their help in the field.

\section{LITERATURE CITED}

Adey WH (1998) Coral reefs: algal structured and mediated ecosystems in shallow, turbulent, alkaline waters. J Phycol 34:393-406

Al-Najjar T (2000) The seasonal dynamics and grazing control of phyto- and mesozooplankton in the northern Gulf of Aqaba. PhD thesis, Bremen University

Andrews JC, Müller HR (1983) Space-time variability of nutrients in a lagoonal patch reef. Limnol Oceanogr 28: $215-227$

Arar EJ, Collins GB (1992) In vitro determination of chlorophyll $a$ and pheophytin $a$ in marine and freshwater phytoplankton by fluorescence. Environmental Monitoring System Laboratory Office of Research and Development, US Environmental Protection Agency, Cincinnati, OH

Arenas FV, de la Lanz EG (1983) Annual phosphorus budget of a coastal lagoon in the northwest of Mexico. Ecol Bull 35:431-440

Atkinson MJ, Carlson B, Crow GL (1995) Coral growth in high-nutrient, low-pH seawater: a case study of corals cultured at the Waikiki Aquarium, Hawaii. Coral Reefs 14: $215-223$

Ayukai T (1993) Temporal variability of the nutrient environment on Davies Reef in the Central Great Barrier Reef, Australia. Pac Sci 47:171-179

Badran MI, Foster P (1998) Environmental quality of the Jordanian coastal waters of the Gulf of Aqaba, Red Sea. Aquat Ecosyst Health Manag 1:75-89

Beekman JW (1990) Mathematical description of heterogeneous materials. Chem Eng Sci 45:2603-2610

Bell PRF (1991) Status of eutrophication in the Great Barrier Reef lagoon. Mar Pollut Bull 23:89-93

Bertuzzi A, Faganeli J, Brambati A (1996) Annual variation of benthic nutrient fluxes in shallow coastal waters (Gulf of Trieste, northern Adriatic Sea). PSZN I: Mar Ecol 17: 261-278

Blanchot J, Charpy L, Le Borgne R (1989) Size composition of particulate organic matter in the lagoon of Tikehau atoll (Tuamotu archipelago). Mar Biol 102:329-339

Bray RN, Miller AC, Geesey GG (1981) The fish connection: a trophic link between planktonic and rocky reef communities? Science 214:204-205

Buddemeier RW, Oberdorfer JA (1986) Internal hydrology and geochemistry of coral reefs and atoll islands: key to diagenetic variations. In: Schroeder JH, Purser BH (eds) Reef diagenesis. Springer-Verlag, Berlin, p 91-111

Callender E, Hammond DE (1982) Nutrient exchange across the sediment-water interface in the Potomac River estuary. Estuar Coast Shelf Sci 15:395-413

Capone DG, Dunham SE, Horrigan SG, Duguay LE (1992) Microbial nitrogen transformations in unconsolidated coral reef sediments. Mar Ecol Prog Ser 80:75-88

Charpy-Roubaud C, Charpy L, Sarazin G (1996) Diffusional nutrient fluxes at the sediment-water interface and organic matter mineralization in an atoll lagoon (Tikehau, Tuamotu Archipelago, French Polynesia). Mar Ecol Prog Ser 132:181-190

Ciceri G, Ceradina S, Zitelli A (1999) Nutrient benthic fluxes 
and pore-water profiles in a shallow brackish marsh of the lagoon of Venice. Ann di Chim 89:359-375

Clavero V, Izquierdo JJ, Fernandez JA, Niell FX (2000) Seasonal fluxes of phosphate and ammonium across the sediment-water interface in a shallow small estuary (Palmones River, southern Spain). Mar Ecol Prog Ser 198:51-60

Crossland CJ, Barnes DJ (1976) Acetylene reduction by coral skeleton. Limnol Oceanogr 21:153-156

d'Elia CF, Wiebe WJ (1990) Biogeochemical nutrient cycles in coral reef ecosystems. In: Dubinsky Z (ed) Coral reefs. Elsevier Science Publishers, Amsterdam, p 49-74

d'Elia CF, Webb KL, Porter JW (1981) Nitrate-rich groundwater input to Discovery Bay, Jamaica: a significant source of $\mathrm{N}$ to local coral reefs? Bull Mar Sci 31:903-910

Entsch B, Boto KG, Sim RG, Wellington JT (1983) Phosphorus and nitrogen in coral reef sediment. Limnol Oceanogr 28: 465-476

Ferrer LM, Szmant AM (1988) Nutrient regeneration by the endolithic community in coral skeletons. Proc 6th Int Coral Reef Symp 3:1-4

Fuentes VA de le G, Espino L (1990) Metabolism as determinant of nutrient exchange in organic-rich sediments of a coastal lagoon. Cienc Mar 16:45-62

Furnas MJ (1992) The behavior of nutrients in tropical aquatic ecosystems. In: Connell DW, Hawker DW (eds) Land use patterns and nutrient loadings of the Great Barrier Reef Region. James Cook University, Townsville, p 162-179

Furnas MJ, Mitchell AW, Gilmartin M, Revelante N (1990) Phytoplankton biomass and primary production in semienclosed reef lagoons of the central Great Barrier Reef, Australia. Coral Reefs 9:1-10

Furnas MJ, Mitchell AW, Skuza M (1993) Nitrogen and phosphorus budgets for the Great Barrier Reef. Final Report to the Great Barrier Reef Marine Park Authority, Aust Inst Mar Sci, Townsville

Gast GJ, Wiegmann S, Wieringa E, van Duyl FC, Bak RPM (1998) Bacteria in coral reef water types: removal of cells, stimulation of growth and mineralization. Mar Ecol Prog Ser 167:37-45

Ginsburg RN (1983) Geological and biological roles of cavities in coral reefs. In: Barnes DJ (ed) Perspectives on coral reefs. Aust Inst Mar Sci, Townsville, p 148-153

Goldner LL (1980) Nitrogen fixation (acetylene reduction) in shallow water Bahamian environments. Bull Mar Sci 30: 444-453

Hallock P, Müller FE, Halas JC (1993) Coral reef decline. Natl Geogr Res Explor 9:358-378

Hatcher RAI, Hatcher BG (1981) Seasonal and spatial variation in dissolved inorganic nitrogen in One Tree Reef lagoon. Proc 4th Int Coral Reef Symp 1:419-424

Hesselein RH (1976) An in situ sampler for close internal pore-water studies. Limnol Oceanogr 21:912-924

Holm NG (1978) Phosphorus exchange through the sedimentwater interface. Mechanism studies of dynamic processes in the Baltic Sea. Contrib Microb Geochem Dep Geol Univ Stockh 3:149

Huettel M, Rusch A (2000) Transport and degradation of phytoplankton in permeable sediment. Limnol Oceanogr 45:534-549

Huettel M, Ziebis W, Forster S (1996) Flow-induced uptake of particulate matter in permeable sediments. Limnol Oceanogr 41:309-322

Hulthe G, Hulth S, Hall POJ (1998) Effect of oxygen on degradation rate of refractory and labile organic matter in continental margin sediments. Geochim Cosmochim Acta 62: $1319-1328$
Johannes RE (1975) Pollution and degradation of coral reef communities. Elsevier Oceanogr Ser 12:13-15

Kinsey DW (1977) Seasonality and zonation in coral reef productivity and calcification. Proc 3rd Int Coral Reef Symp 2: 383-388

Klinker J, Reiss Z, Kropach C, Levanon I, Harpaz H, Shapiro Y (1978) Nutrients and biomass distribution in the Gulf of Aqaba (Eilat), Red Sea. Mar Biol 45:53-64

Kobluk DR, van Soest RWM (1989) Cavity-dwelling sponges in a southern Caribbean coral reef and their paleontological implications. Bull Mar Sci 44:1207-1235

Larned ST (1998) Nitrogen- versus phosphorus-limited growth and sources of nutrients for coral reef macroalgae. Mar Biol 132:409-421

Lerman A (1979) Geochemical processes, water and sediment environment. John Wiley \& Sons, New York

Levanon-Spanier I, Padan E, Reisis Z (1979) Primary production in a desert-enclosed sea - the Gulf of Eilat (Aqaba), Red Sea. Deep-Sea Res 26:673-685

Lewis JB (1985) Groundwater discharge onto coral reefs, Barbados (West Indies). Proc 5th Int Coral Reef Symp 6: $477-481$

Li YH, Gregory S (1974) Diffusion of ions in sea water and in deep sea sediment. Geochim Cosmochim Acta 38: 703-714

Lindell D, Post AF (1995) Ultraphytoplankton succession is triggered by deep winter mixing in the Gulf of Aqaba (Eilat), Red Sea. Limnol Oceanogr 40:1130-1141

Marsh JA (1977) Terrestrial inputs of nitrogen and phosphorus on fringing reefs of Guam. Proc 3rd Int Coral Reef Symp 1:331-336

Meyer JL, Schultz ET (1985) Tissue condition and growth rate of corals associated with schooling fish. Limnol Oceanogr 30:157-166

Meyer JL, Schultz ET, Helfman GS (1983) Fish schools: an asset to corals. Science 220:1047-1049

Nixon SW, Pilson MEQ (1983) Nitrogen in estuarine and coastal marine ecosystems. In: Carpenter ED, Carpenter DG (eds) Nitrogen in the marine environment. Academic Press, New York, p 565-648

Olson RJ (1981) Differential photoinhibition of marine nitrifying bacteria: a possible mechanism for the formation of the primary nitrite maximum. J Mar Res 39:227-238

Richter C, Wunsch M (1999) Cavity-dwelling suspension feeders in coral reefs - a new link in reef trophodynamics. Mar Ecol Prog Ser 188:105-116

Richter C, Wunsch M, Rasheed M, Koetter I, Badran MI (2001) Endoscopic exploration of Red Sea coral reefs reveals dense populations of cavity dwelling sponges. Nature 413: 726-730

Risk MJ, Müller HR (1983) Pore water in coral heads: evidence for nutrient regeneration. Limnol Oceanogr 28: 1004-1008

Sansone FJ (1985) Methane in the reef flat pore-waters of Davies Reef, Great Barrier Reef (Australia). Proc 5th Int Coral Reef Symp 3:415-419

Schuhmacher H, Mergner H (1985) Quantitative Analyse von Korallengemeinschaften des Sanganeb-Atolls (mittleres Rotes Meer). 2. Vergleich mit einem Riffareal bei Aqaba (nördliches Rotes Meer) am Nordrande des indopazifischen Riffgürtels. Helgol Wiss Meeresunters 39:419-440

Shashar N, Feldstein T, Cohen Y, Loya Y (1994) Nitrogen fixation (acetylene reduction) on a coral reef. Coral Reefs 13:171-174

Shum KT, Sundby B (1996) Organic matter processing in continental shelf sediments - the subtidal pump revisited. Mar Chem 53:81-87 
Smith SV, Kimmerer WJ, Laws EA, Brock RE, Walsh TW (1981) Kaneohe Bay sewage diversion experiment: perspectives on ecosystem responses to nutritional perturbation. Pacific Sci 35:279-402

Sorokin YI (1993) Coral reef ecology. Springer-Verlag, Berlin

Souvermezoglou E, Metzl N, Poisson A (1989) Red Sea budgets of salinity, nutrients and carbon calculated in the Strait of Bab-El-Mandab during the summer and winter seasons. J Mar Res 47:441-456

Strickland JDH, Parsons TR (1972) A practical handbook of seawater analysis, 2nd edn. Bull Fish Res Board Can $167: 310$

Szmant-Froelich A (1983) Functional aspects of nutrient cycling in coral reefs. NOAA Symp Ser Undersea Res 1:133-139

Szmant AM, Forrester A (1996) Water column sediment nitrogen and phosphorus distribution patterns in the Florida Keys, USA. Coral Reefs 15:21-41

Torrance DC (1991) Deep ecology: rescuing Florida's reef. Nat Conserv July-Aug, p 9-17

Tribble GW, Sansone FJ, Andrews CC, Smith SV (1986) Organic geochemistry of reef interstitial water. EOS Trans Am Geophys Un 67:997

Tribble GW, Sansone FJ, Li YH, Smith SV, Buddemeier RW (1988) Material fluxes from a reef framework. Proc 6th Int Coral Reef Symp 2:577-582

Editorial responsibility: Gotthilf Hempel, Bremen, Germany
Tribble GW, Sansone FJ, Smith SV (1990) Stoichiometric modeling of carbon diagenesis within a coral reef framework. Geochim Cosmochim Acta 54:2439-2449

Venrick El, McGowan JA, Mantyla AW (1973) Deep maximua of photosynthetic chlorophyll $a$ in the Pacific Ocean. Fish Bull 71:41-52

Ward F (1990) Florida's coral reefs are imperiled. Natl Geogr 178:114-132

Wells SM (1988) Coral reefs of the world, Vol 2. Indian Ocean, Red Sea and Gulf. The IUCN Conservation Monitoring Center, Cambridge, UK

Wiebe WJ, Johannes RE, Webb KL (1975) Nitrogen fixation in a coral reef community. Science 188:257-259

Wilkinson CR, Williams DMcB, Sammarco PW, Hogg RW, Trott LA (1984) Rates of nitrogen fixation on coral reefs across the continental shelf of the central Great Barrier Reef. Mar Biol 80:255-262

Williams SL (1984) Uptake of sediment ammonium and translocation in the marine green alga Caulerpa cupressoides. Limnol Oceanogr 29:374-379

Williams SL, Gill IP, Yarish SM (1985) Nitrogen cycle in back reef sediments. Proc 5th Int Coral Reef Symp 3:389-394

Zieman JC (1982) The ecology of the seagrasses of south Florida: a community profile. US Fish Wildl Serv FWS/ OBS-82/25 123

Submitted: May 3, 2001; Accepted: January 31, 2002

Proofs received from author(s): July 8, 2002 